\title{
Profit rates and asset-price inflation in the Spanish economy
}

\author{
Juan Pablo Mateo Tomé*a / Maximiliano Francisco Nieto Ferrández \\ a Universidad Complutense de Madrid, Departamento de Economía Aplicada, Estructura e Historia, Campus de Somosaguas, \\ 28223 Pozuelo de Alarcón, Spain \\ b Universidad Miguel Hernández, Departamento de Ciencias del Comportamiento y Salud, Área de Psicología Social, Avda. de la \\ Universidad s/n, 03202 Elche, Spain
}

Received: 19 November 2020 / Accepted: 8 April 2021

\begin{abstract}
The paper provides an in-depth analysis of profitability in Spain between 1995 and 2014, showing that behind the asset-price inflation of the growth period and its corresponding macroeconomic imbalances, an underlying problem of capital valorization can be found. For this purpose, a study of various measures of profitability is carried out based on the concept of productive labor and highlighting the role of finance (interest rates and indebtedness). The evolution of the profit rate in previous years is also shown, together with a comparison with countries in the Eurozone, both in the most advanced areas and in the periphery. The paper reveals the large extent of the underlying profitability crisis, with a huge fall of profit rates from the late sixties, during the period of the housing boom, and throughout the subsequent recession. In addition, this drop in profitability stands out in relation to other economies of the European periphery. Hence, the study puts the rate of profit at the center of the debate on the Great Recession in Spain, despite its absence in much of the economic literature.
\end{abstract}

\section{Keywords}

Profit rate; interest rates; fictitious capital; Spain; Eurozone.

\section{Taxas de beneficio e inflación do prezo dos activos na economía española}

\section{Resumo}

Este artigo analiza en profundidade a rendibilidade do capital en España entre 1995 e 2014, e mostra o problema subxacente de valorización do capital detrás da inflación dos activos propia do período de crecemento, e os seus correspondentes desequilibrios macroeconómicos. Para iso, realízase un estudo de diversas medidas da rendibilidade a partir do concepto de traballo produtivo, con especial énfase no papel das finanzas (tipos de xuro e endebedamento). Á súa vez, abórdase a evolución da taxa de beneficio en anos anteriores, xunto cunha comparación con países da Eurozona, tanto nas economías máis avanzadas como na periferia. A investigación revela a amplitude da crise de rendibilidade subxacente, cunha importante caída das taxas de ganancia desde finais dos anos sesenta, durante o período do boom inmobiliario, así como ao longo da recesión posterior. Ademais, este descenso da rendibilidade destaca en relación con outras economías da periferia europea, de aí que o estudo sitúe a taxa de beneficio no centro do debate sobre a Gran Recesión en España, a pesar da súa ausencia en gran parte da literatura económica.

\section{Palabras clave}

Taxa de beneficio; tipos de xuro; capital ficticio; España; Eurozona.

JEL Codes: F60, E01, E32, E40, 052.

\footnotetext{
*J. P. Mateo: jpmateo@ucm.es (corresponding author), M. F. Nieto: m.nieto@umh.es
} 


\section{Introduction: The profit rate and the crisis}

The purpose of this article is to measure different indexes of the profit rate $(r)$ in Spain along the period between 1995-2014 from a political economy perspective, including the phase of growth (1995-2008) and the following deep depression (2008-2013). The study ends in 2014, when the profit rate reaches the minimum. Indeed, the following increase is very weak, though the Spanish economy already resumes growth in 2014.

The hypothesis is the existence of an underlying profitability problem behind the housing boom -or the construction assets (mainly residential) inflation- leading to the Great Recession in Spain. That is, given the imbalances of the expansionary phase and the intensity of the subsequent crisis, one of its foundations must be a reduced level of profitability and/or a steep decline. Therefore, this paper tries to shed light on the role of profitability on economic cycles, and specifically, in relation to the Great Recession.

This study includes several specific issues, both in time and space. First, it requires historically locating profitability in a long-term perspective, as well as to reveal the implications of using different expressions according to the specific context. In this sense, given the 'price-effect'1 ${ }^{1}$ of the housing boom driving economic growth after 1999, the use of different indicators of profitability turns out to be important, and thus incorporating interest rates and debt. On the other hand, a comparison with other countries of the Eurozone has been carried out in order to put the Spanish case in context and, thus, to grasp certain particularities.Methodologically, the research deals with various indicators of profitability based on the concept of productive labor, which implies excluding certain activities for the measure of both profit and the capital stock. In addition, a comparison of measures is carried out due to statistical availability, as well as the theoretical approach, incorporating in turn the business ratios provided by the Banco de España, which could strengthen the validity of results. When thus compared, and considering the relevance of the financial sphere in the housing boom, the role of interest rates and debt stands out, as it could conceal profitability problems by means of a conjunctural fall in interest rates and rising indebtedness. In turn, an advance in the degree of specificity of profitability indicators is enabled.

If, as claimed in the paper, there is a problem regarding profitability in Spain, then the set of macroeconomic imbalances would be rather the consequence of this profitability problem, and thus related to the type of capital accumulation and external insertion (see among others, Buendía \& MoleroSimarro, 2018; Mateo, 2019). In this sense, profitability is key to fully grasp the so-called financialization of the Spanish economy (Álvarez, 2012; Ferreiro, Gálvez \& González, 2016; Sanabria \& Medialdea, 2016), revealed in the role of interest rates and indebtedness. This even makes it possible to also address the debate about the current account deficit, among those who point out the loss of competitiveness due to labor costs, or others who highlight the role of financial flows (see Guschanski \& Stockhammer, 2020).

The structure of the paper is as follows. First, theoretical and methodological questions are addressed. Subsequently, and in order to provide a time perspective, we analyze the measures of the general rate of profit from a historical perspective while considering various statistical issues. The next section incorporates the financial sphere in order to advance analytically in the degree of concretion in the study of profitability. Towards the end, certain conventional measures are mentioned and, in the last part, a comparison of Spain with several countries of the Eurozone is carried out with the purpose of showing a geographical context of the level and dynamics of the profit rate in Spain.

\section{Theory and methodology}

\subsection{Theoretical aspects}

The profit rate is a central variable in a political economy-based analysis (Shaikh, 2016). It largely explains investment and, consequently, economic growth, so its fall (and/or low level) lies behind the

\footnotetext{
1 On this concept, we refer to López \& Rodríguez (2011), Mateo (2019), and the general framework of Brenner (2006).
} 
historical recurrence of crises (Kliman, 2011; Roberts, 2016; Shaikh, 2016). As claimed by Wells (2007, p. 2), "the rate of profit is central to understanding the capitalist market economy as a dynamic entity evolving in time".

This concept -the rate of profit- is however quite complex, both theoretically and empirically (Mateo, 2019). Indeed, it relies on economic theory, and specifically the theory of value, from which to justify the concept of unproductive activity -as will be shown in the following section. The starting point is the general or gross profit rate $(r)$, which indicates the capacity to produce surplus, that is, the extent to which capital achieves its objective. From this rate, the most concrete analysis can address the so-called net profit rate of enterprise $(r-i)$, for which the lower limit of investment, the interest rate $(i)$, is crucial.

The particularity of Spain lies in its incorporation into the European Monetary Union (EMU), which has somehow changed the causality $r \rightarrow i$, leading to an extraordinary fall in the cost of financing without a direct link to ' $r$ '. In other words, the dynamics of the interest rate has, to a certain extent, had an exogenous character, so its level has been outside of the internal productive conditions until the outbreak of the crisis. This low level of interest rates has encouraged -but not created- the rise of indebtedness.

Thus, the housing boom of the Spanish economy generated a kind of 'duality' between the accounted profit and the generated surplus, in the sense that it can be claimed that part of the surplus has had a certain 'fictitious' character in light of the dichotomy between the price of residential assets and the evolution of productive development (Jones, 2013; Moseley, 2013). Finance has been inextricably linked to the valorization process by means of this kind of price-effect inasmuch as the expectations for revaluation of certain assets have driven indebtedness. Put in another way, the underlying falling rate of profit has been hidden by, or to a great extent has boosted, the asset-price inflation relative to their value (productivity) foundations (Potts, 2010; Roberts, 2016).

Debt is a form of fictitious capital which breaks the equality between income and the generation of surplus (Jones, 2013), as it creates artificial demand. At least in the short term, government, corporate and household debt boost directly or indirectly business profitability (Milios \& Sotiropoulos, 2009) by means of changes in relative prices (Shaikh, 2016), or the asset-price inflation (Hossein-Zadeh, 2016), and thus, employment and production. Yet, if commodities are not realized in the market, profits are not backed by a productive activity, then debt is not paid back to creditors and the underlying problem of valorization appears as a debt problem. Moreover, it is important to note that debt does not cause the fall in profitability but amplifies its movements. It makes profitability rise more during the boom phase, but also falling further during the crisis (Kliman, 2011).

When the crisis appears the rise in interest rates is a systemic (and endogenous) requirement for preserving the quality of money and the effective accomplishment of their functions. For money to adequately represent the value generated, devaluation of goods is required. The rise in the interest burden very often leads to the idea of a finance-led profit-squeeze, or the financialization theory of crises $^{2}$. In this line of analysis, financialization in Spain would be defined as

The increase in the value of financial assets has been notably higher than that of the very foundations of productive activity, and the weight of financial income has increased in the national income as a whole. In particular, the central feature of the process of financialization of the Spanish economy has been given by the huge credit bubble accumulated since the late nineties (Álvarez, 2012, p. 1).

Although the huge relevance of finance is largely recognized, the controversies liesin the underlying causality: if interest rates and/or indebtedness should be taken as the starting point for the account of the Spanish recession, or quite the contrary, finance would have been the triggering factor arising out of a profitability problem (see Mateo, 2021). This paper argues in favor of the last view, so the profit rate is at the center of the analysis of the Spanish process of capital accumulation. Therefore, finance is

\footnotetext{
2 As in this paper it is only possible to show a broad exposition, see Mateo (2011) and Mavroudeas \& Papadatos (2018) for a thorough critical account.
} 
not the starting point, as if it were an independent sphere within the circuit of capital but instead the level of development of productive forces which is the entry point, associated to the capacity to generate surplus, meaning that it is a low profit rate that makes both interest rates and debt become too high.

\subsection{The measure of profitability}

Although the correct measurement of the rate of profit is of the utmost importance, it is not possible to accurately quantify it, so it will be necessary to show different measures. Even though this paper does not address the extensive debate on productive and unproductive labor ${ }^{3}$, there are two sectors excluded: i) Finance and Real Estate (FIRE) [branches 64-66, 68], given the centrality of the banking system in the housing boom and the large presence of circulation activities, channeling funds to both non-financial corporations (NFC) and households (HH), and the fictitious part within the Real Estate sector, although they include some productive activities; and ii) Government (GOV) [public administration and defense; compulsory social security, 68], because it is mainly made up of non-market activities, so the value added is measured by the labor cost.

For the measurement of profit $(P)$, or the net operating surplus (NOS) as the proxy for surplus ( $s p$ ), the starting point is the difference between gross domestic product $(G D P)$ and wages $(W)$, and also excluding taxes less subsidies on production $(T p)$, as well as depreciation $(D E P)$, for all the productive activities $(p)^{4}$.

$$
P=\sum_{p}(G D P-W-T p-D E P)
$$

The capital stock $(K)$ is taken from the Mas, Pérez \& Uriel (2011), by far the most complete and rigorous database, being the reference for the EU-KLEMS project (Mas, Pérez \& Uriel, 2013) ${ }^{5}$. This measure is: i) at replacement costs, although there are also strong reasons for the use of the capital stock at historic cost, as the adherents of the Temporal Single System Interpretation (TSSI) claim (Kliman, 2011); ii) on net terms (net), though Shaikh (1999) explains the advantages of the gross capital stock (and at replacement cost), and iii) without residential assets $(n r)$, and excluding the activities considered unproductive.

$$
K_{n r}^{n}=\sum_{p}(\text { Total assets }- \text { Residential assets })_{t-1}
$$

Where $K$ in the previous year $(t-1)$ is used for measuring ' $r$ ' in the current year $(t)$, as is done in this literature (Roberts, 2016). Consequently, the profit rate $(r)$ is given by:

$$
r=\sum_{p}\left(\frac{N O S}{\left(K_{n r}^{n e t}\right)_{t-1}}\right)
$$

Nevertheless, this measure of profitability still incorporates a flow of income that is not part of the business surplus: the mixed income (MI). The MI corresponds to the self-employed and entrepreneurs

\footnotetext{
3 On this topic, see Mateo (2007), for which two opposing approaches from a political economy approach can be found in Shaikh \& Tonak (1994) and Cámara (2006). In Mateo (2019) there is a more exhaustive explanation of both Finances and Real Estate activities in relation to the empirical measure of profitability.

${ }^{4}$ This expression includes the mixed income, but the National Accounts do not provide disaggregated series. Moreover, it has to be considered that a great part of senior executives' compensation could belong indeed to the surplus.

5 This database, very disaggregated into branches of activity, allows for a more rigorous analysis than AMECO or Prados de la Escosura (2020), while the new database on the gross and net capital stock provided by the Instituto Nacional de Estadística (INE, 2020) only begins in 2000.
} 
without employees, thus belonging to a non-capitalist circuit. However, there are cases where variable capital is assumed to take the form of mixed income, as happens with the 'false self-employed' (see Mateo, 2007, 2012). Yet, there are statistical problems in the National Accounts: empirically, data can be found in the European Commission for the total economy, and both INE and the Organisation for Economic Co-operation and Development (OECD) database show disaggregated data by institutional agents, not by sectors of activity. Another problem is to delimit the part of the capital stock that belongs to this area, for which no data exists, so this measure of the 'capitalist' or 'corporate' NOS (NOS ${ }_{\text {cor }}$ ) can only be a proxy:

$$
N O S_{\text {cor }}=N O S_{p}-M I_{F I, G O V}
$$

The NOS of the corporate sector is measured by taking out the $M I$ of finance $(f i)$ and government (gov), but it is only used if made explicit in the text.

In the case of conventional measures of profitability, despite including certain assets that are not part of the concept of capital in a political economy approach, they are, however, relevant since the purpose is to have a complete picture of the complex concept of profitability in a context of asset-price inflation. The indices of profitability used in this research are the following:

$-[r]=$ general rate of profit, i) for 1995-2014, NOS (INE, 2019a); $K$ (Mas et al., 2011), in productive activities; ii) for 1965-2014, NOS (European Commission, 2019) and $K$ (Mas et al., 2011), the whole economy; iii) for the comparison in the Euro area, the only difference is that all the assets of the capital stock are taken, but only for the above-mentioned productive activities, and NOS and $K$, from OECD $(2019)^{6}$.

$-[O R N A(R 1)]=$ ordinary return of net assets (Banco de España, 2019c, 15.7-9) ${ }^{7}$. Profits: net ordinary result (without atypical transactions) + financial expenses, excluding depreciation and provisions + net worth or equity + interest - bearing borrowing.

$-[O R E(R 3)]=$ ordinary return on equity: net ordinary result / equity (Banco de España 2019c, 15.13-15).

$-[R E(F S I .2)]=$ return on equity (Banco de España, 2019c, 15.29).

-Interest burden $=$ interests on borrowed funds / (gross operating profit + financial revenue) (Banco de España, 2019c, 15.26-27).

-Debt ratio $(E 2)=$ external interest-bearing funds / (gross operating profit + financial revenue) (end-of-year balance) (Banco de España, 2019c, 15.24-25).

-Spread $(R 4=R 1-R 2)=$ spread return on investment - cost debt (Banco de España, 2019c, 15.16-18).

Other complementary ratios of profitability are shown, such as the increase in the stock of debt to profit ratio $(\Delta d e b t / P)$ and profit to inputs ratio $(P / I C)$.

\subsection{Review of the literature on capital profitability in contemporary Spain and the Eurozone}

The study of the rate of profit in the Spanish economy is not only important to understand the macroeconomic dynamics, and in particular this economic crisis, but also because of the relative scarcity of empirical research on profitability. On the one hand, there are long term estimations following a heterodox political economy approach, but only reaching the first years of this paper's time span, such as Guerrero (2006) and Cámara (2007), who cover the period 1954-2001, then updated by Nieto until

\footnotetext{
${ }^{6}$ The reason is the availability of data in the OECD database for a number of countries. However, the results are very similar if residential assets are excluded, because when excluding the Real Estate sector, the great part of them are thus eliminated.

7 In parentheses, the abbreviation used here and in the source, as in this case ORNA is $R 1$ in the Banco de España, and the place to find the variable, which is in chapter 15 section 29: 15.29 .
} 
2003 (Nieto, 2006) and Cámara (2008) up to 2006. Therefore, these authors do not adjust the total amount of the operating surplus and do not address financial aspects. As a result, it seems to be a relative stability of profitability in the years after 1995, or even a recovery, in opposition to the measures of this research.

As for the authors that have covered most of the last two decades, there are huge methodological differences despite the common political economy approach. Boundi (2014) ends his study in 2012, but he does not exclude unproductive activities, and uses the capital stock of the current year $\left(K_{t}\right)$ for measuring the profit rate, instead previous year's capital $\left(K_{t-1}\right)$. Murillo (2015) discounts the mixed income from the gross operating surplus on the assumption that it is equivalent to the wage, and his measure of profitability only decreases between 2002 and 2007, so, in this last year, it was slightly more than 3\% lower than in 1996. Roberts (2016) calculates the rate of profit from 1950 to 2010, but following the AMECO database, so the movement of his ratio since 1995 is very different, since it increases between 1996 and 2001-2002, but with a subsequent fall of more than 40\% until 2010, although substantially lower since 1995. Methodologically, this paper has similarities with Mateo (2019), although the latter does not present measures regarding the financial sphere, nor does it incorporate a comparison with Eurozone and without considering indebtedness.

Franconetti (2015) carries out a comparative study of the profit rate of Spain with respect to the US and several European countries, but from a long-term perspective (1961-2013) and in which, nevertheless. he focuses on the regions of Spain. On the one hand, he shows a rate of profit for the total economy based on AMECO, which presents a similar general profile, although with a less abrupt decline. On the other, he takes the database BD.MORES -which covers the period 1960-2008- to carry out a more systematic study in Spain. This author excludes the same activities, but without deducting taxes and the consumption of fixed capital in the surplus. The methodology for the capital stock is similar, but instead of adding non-residential assets from productive economic activities, he takes the total stock and then discounts the total stock of the unproductive sectors, also with $t-1$ (previous year). However, his procedure presents some problems, as the author himself recognizes, since he starts from a series at constant prices that then converts to current prices using the gross value added (GVA) deflator. Moreover, inasmuch as he starts from the series for each Spanish region in order to measure the total capital, there is a growing gap each year. As a result, the dynamics of profitability differ considerably: the profit rate went from $16.1 \%$ to $11.9 \%$ between 1995 and 2007 , a drop of only $26 \%$.

Following other theoretical approaches and empirical methodologies, López, Dávila \& López (2013) and López (2015) take the Levy-Kalecki equation for the estimation of business profits, with the particularity of considering the extra profits arising from the valuation of assets, but with an opposite causality, that is, profits depending on spending. From a post-Keynesian approach inspired by Kaleki, López \& Palazuelos (2016) address profit and investment in Spain. However, they only take one indicator of the profit rate, which is disaggregated into sectors, since their objective is to link it with other macroeconomic categories, they use instead the EU-KLEMS database, and the paper only covers the period 1994-2007 period. This profit rate remains at 9-9.5\%, a very different evolution. In a similar way, del Río (2015) analyzes the possible disconnection between profits and investment in Spain within the financialization debate, for which he presents an estimate of the profit rate from AMECO, that barely drops as well.

From an orthodox perspective, Pérez (2012) relies on the measures from the Banco de España, including a brief comparison with France, Germany and Italy by using the Bank for the Accounts of Companies Harmonized (BACH) database. Interestingly, this author claims that in 2007 the profitability of Spanish companies was lower than that of French and German companies in all major sectors except construction' (Pérez, 2012, p. 171). The International Monetary Fund (IMF, 2013) compares Earnings Before Interest Taxes Depreciation and Amortization (EBITDA) measures with total assets, debt ratios and banking profitability by corporation size in Spain, France, Germany, Portugal between 2001 and 2011. Finally, Maudos \& Fernández (2014) analyze profitability and indebtedness of Spanish companies by sector of activity and size, also using the BACH database. 
On the other hand, several accounts of the crisis are rooted on financial aspects, such as interest rates or indebtedness. However, profitability does not seem to have any explanatory role, or it would just be a consequence of the crisis. Estrada, Jimeno \& Malo (2009), Vara (2009) and Muñoz de Bustillo (2014) -from Neoclassical, Austrian and Keynesian approaches, respectively- points to European Central Bank (ECB) monetary policy, as it led to an excessive low level of interest rates, in turn generating the housing boom, which is completed by Carballo-Cruz (2011) with the fiscal policy. For Ferreiro et al. (2016) there was a profit-squeeze, but the fundamental factor lies in the financial sphere, since "the greater payment of interest and dividends has gone at the expense of lower retained profits" (Ferreiro et al., 2016, p. 105).

In quite a similar line, Pérez Caldentey \& Vernengo (2018, p. 305) claim that the depression had two fundamental causes, "a widening deficit in the non-financial corporate sector and a declining trend in profitability" but for them, the fall in profitability would have merely deepened the contradictions inherent in the excessive indebtedness, and it was explained by increasing relative unit labor costs. Febrero \& Bermejo (2013), as well as Sanabria \& Medialdea (2016), argue that it is a recession caused by private over-indebtedness, or balance-sheet recession, which would explain the financial disorders. In this framework, even debt -not profitability- is claimed as being the leiv motiv of the Spanish economy, that is, a debt-led private expenditure type of growth (Ferreiro et al., 2016).

In relation to the Euro area, there is a lack of in-depth empirical research. There are some long term studies, but empirically limited -in so far as only the general profit rate is measured, and for the whole economy, without adjustments-, and moreover, taking only some countries. Maito (2018) has taken the United Kingdom, Germany and Netherlands since the 19th century, Trofimov (2017) the group of OECD economies in 1964-2009, while Roberts (2016) only analyzes Germany, Spain, Italy and Greece as well in a long-term perspective. Albano de Freitas (2017) is the only one who addresses the average profit rate in the Euro area, but unfortunately his research ends in 2009, and methodologically is quite different, as he takes the AMECO database. Recently, Mateo \& Boundi (2021) made a comparison of profitability indices across the Eurozone during a larger period, not limited to the recession, and incorporating the volume of surplus and determinants such as investment and productivity, employment or price deflators.

To sum up, these studies do not address the implications that the Spanish model of valorization had on the rate of profit, hence the financial sphere is not integrated nor compared with conventional indicators of profitability, and there is no comparison with other profit rates in the Eurozone. Contrary to these accounts, it is our claim that behind macroeconomic imbalances -included financial ones- 1 a profitability problem lays, but because of the price effect, low profitability has been hidden by the assetinflation boom, so the research requires the use of different measures of profitability.

\section{The general rate of profit}

\subsection{Historical background and productive activities}

The first issue is to measure profitability in a long term historical framework, which provides the context of our period of reference (1995-2014). Figure 1 shows the general downward trend of the profit rate of the whole economy since 1965 . After a brief increase from $33.1 \%$ to $36.4 \%$ during the expansive phase of $1965-1974$, it declined by $33.4 \%$ in the years of relative stagnation (1975-1983). Then, there is partial recovery in the second half of the eighties, a subsequent fall and, afterwards, a very weak rise does follow until 1995. In this year, the profit rate only comes back to the 1983 trough.

The analysis of the economic boom after 1995 is thus characterized by a historically low level of profitability in this first year: 30\% below the 1965-1974 average, $20 \%$ with respect to the $1975-1979$ average, and even almost $5 \%$ lower than the level of the recessive phase of the early 1980s. Globally, the average rate of profit in 2010-2014 is 58\% lower than in 1965-1974. Unlike previous expansive phases, 
the growth phase of 1995-2008 does not impel an increase of the rate of profit, but develops parallel to an abrupt fall in profitability.

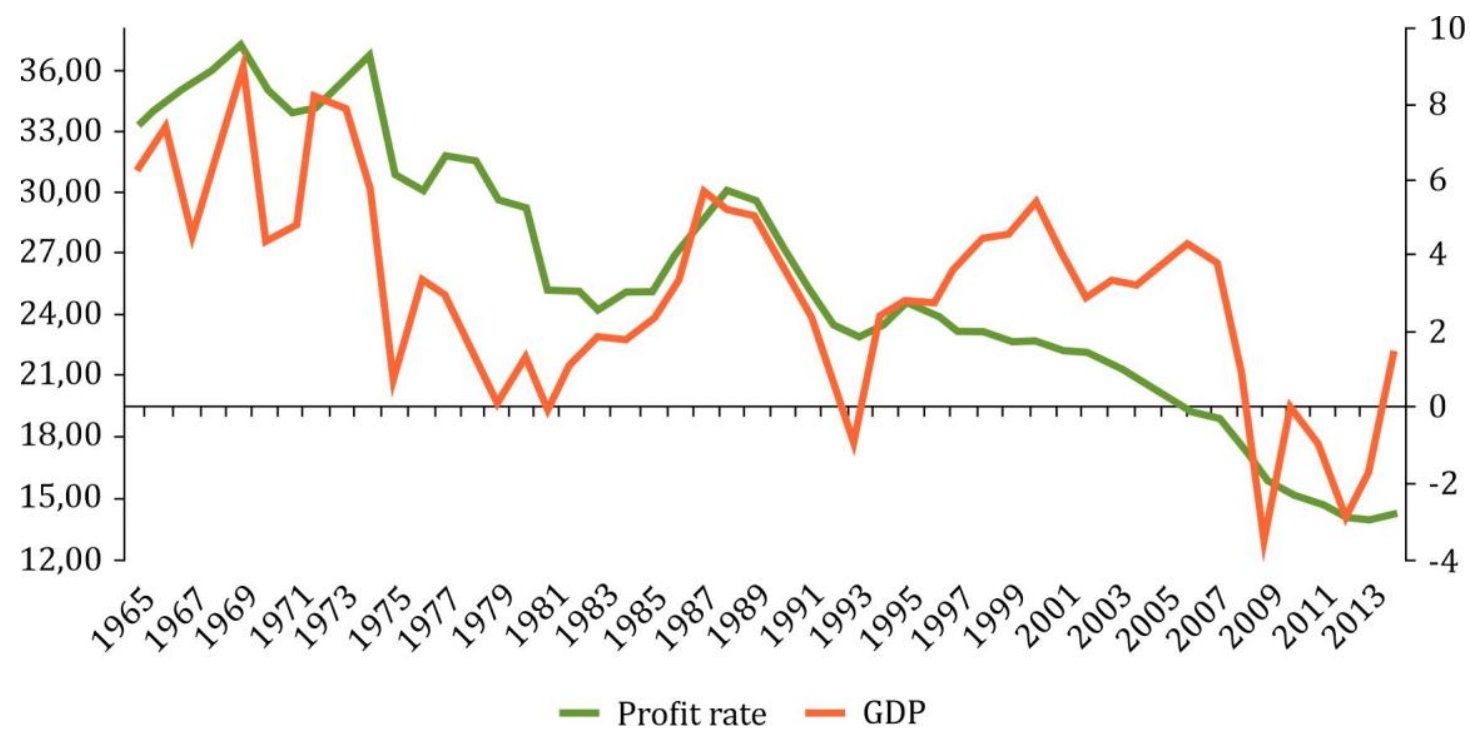

Figure 1. Long term rate of profit and rates of change of GDP (1965-2014) (\%). Note: profit rate for the whole economy (left) and annual rates of change of GDP at 2010 constant prices (right). Sources: European Commission (2019) and Mas et al. (2011).

Focusing now on the period 1995-2014, Figure 2 shows that the exclusion of the above-mentioned FIRE and GOV activities has decisive analytical implications. While the total profit rate falls by $42 \%$, the deduction of FIRE activities led to a greater downward trend from 1999-2000, reaching almost a 60\% decline. If GOV is excluded, the fall is only slightly weaker, $-58 \%$.

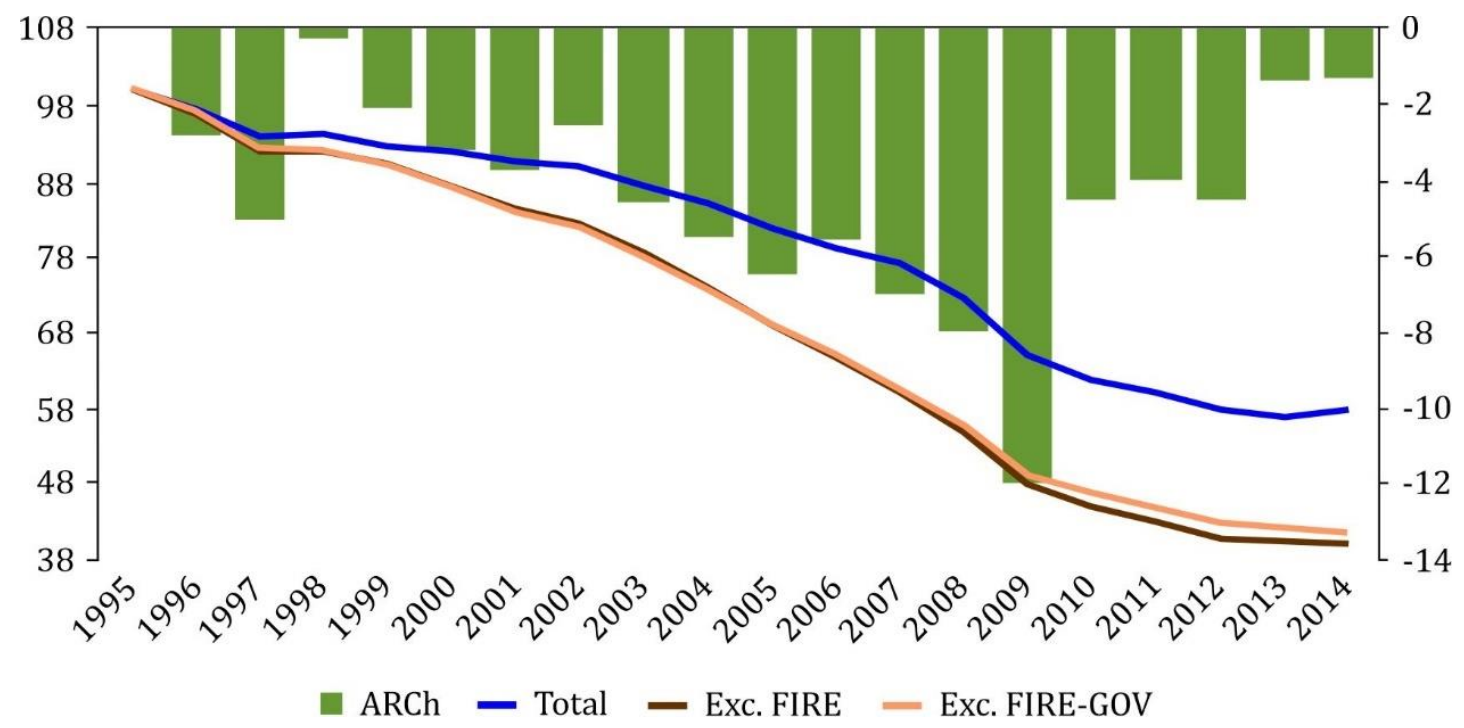

Figure 2. Measures of profitability $(1995=100)$ and annual rates of change (\%). Notes: profit rate (left): i) for the whole economy, ii) excluding FIRE activities, and iii) excluding FIRE and GOV activities; and annual rates of change of the profit rate (exc. FIRE-GOV) (right). Sources: INE (2019a) and Mas et al. (2011). 
Another aspect worth emphasizing is the continuous decline of profitability, since only the total profit rate reached an increase in 1998 and 2014. Considering the more concrete measure, the annual average rate of fall during the first five-year subperiod is $2.70 \%$, which amounts to $-6.16 \%$ between 2000 and 2009. Figure 3 shows estimations of the total profit rate discounting mixed income in the numerator, and the corresponding part of the capital stock. The exclusion of the first one using the INE/OECD database reduces the extent of the deterioration of profitability in 2005-2008, with a total decline equivalent to that of the profit rate of the whole economy, $-42 \%$. Yet, the measure using AMECO's estimate of the mixed income follows a closer path to the general profit rate, even falling over $-60 \%$.

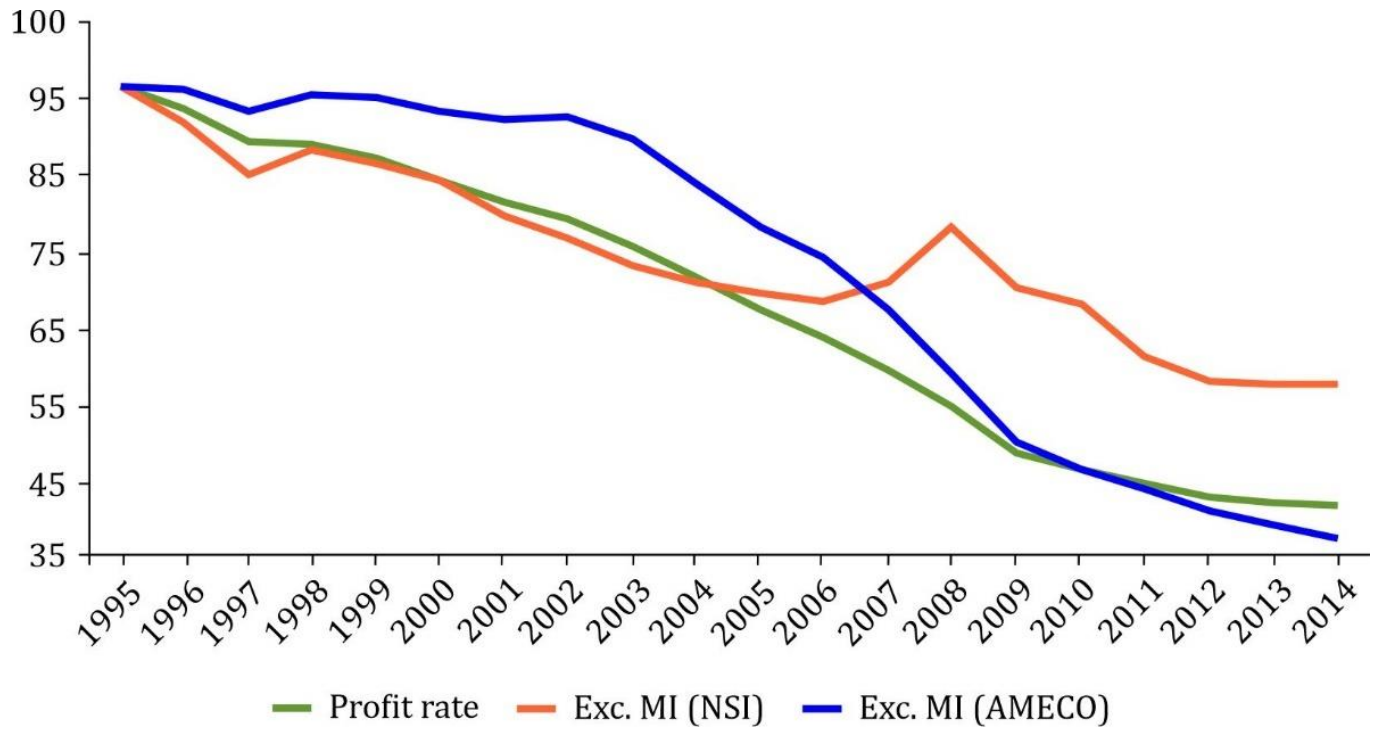

Figure 3. The profit rate and mixed income $(1995=100)$. Note: general profit rate (productive activities) compared with measures excluding mixed income (MI) using INE/OECD and AMECO databases. Self-employment's capital stock is calculated by applying the relative weight of household`s consumption of fixed capital in total depreciation. Sources: European Commission (2019), Mas et al. (2011), INE (2019a) and OECD (2019).

Two aspects must be pointed out in relation to this issue. First, the process of relative increase of wage earners in the total force labor continued throughout the boom phase (1995-2008), since waged labor in relation to total employment went from 79\% to 86\% (INE, 2019a). Second, it should be noted that the business structure in Spain is extraordinarily atomized. In 1999, 55\% of the business units had no employees, a percentage that fell to 50\% in 2004-2006, but with the crisis it returned to the initial level in 2012 (INE, 2019b). According to conventional rates of profitability, larger companies -those with more than 250 employees- have gross profitability levels over net assets above small and medium enterpreises (SMEs) only since 2005, with lower volatility, and in addition, the crisis involves a clear stratification by size (see Banco de España, 2019c). Therefore, it can be inferred that, other than statistical problems and theoretical controversies, the underlying problem of profitability spurred certain duality from 2005-2006 to the detriment of independent producers and SMEs, which is consistent with the profit rate net of mixed income following INE/OECD estimates.

Another problem with the measure used is that only the fixed part of the capital stock is taken, as no data on capital turnover is available in order to calculate the stock of circulating capital, but the cost of inputs has represented a larger part of the total cost structure during the growth period (Figure 4), accounting for $65 \%$ in $1995,72 \%$ in 2007 , and then falling because of the recession. Similarly, inputs represented 50\% of total gross production in 1995 and 10 percentage points more in 2007. 


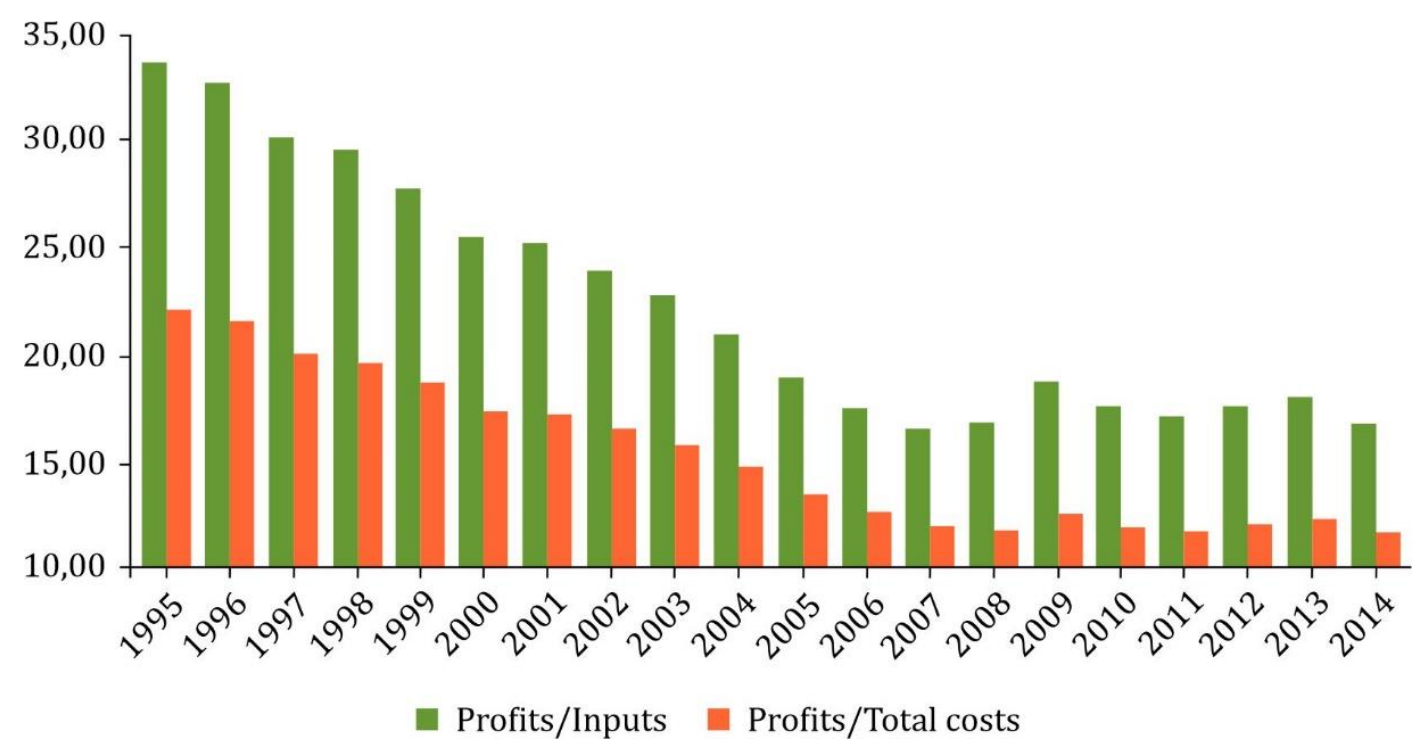

Figure 4. Profit-inputs and profit-total costs ratios (\%). Notes: net operating surplus, inputs and total costs (inputs + wages) of productive activities. Source: INE (2019a).

Given the increase in the cost of circulating constant capital, the profit-input ratio has fallen by $51 \%$ between 1995 and 2007, and despite some recovery during the first part of the recession, the global decline slightly surpasses $50 \%$. In the case of profit-total cost ratio, the fall is similar, only 3-4 points lower: $-46 \%$ and almost $-48 \%$ in 1995-2007 and 1995-2014 respectively. It can be claimed that the measure of profitability in relation to the stock of both fixed and circulating capital would show a still higher fall.

\subsection{Profitability, interest and debt}

The fall in the general rate of profit $(r)$ has been offset by the extraordinary drop in interest rates (i), which has been proportionally higher, and so boosting the net profit rate of enterprise $(r-i)$ (Figure 5). These low interest rates have worked as a countervailing force to the underlying difficulty in valorization, but only stretching the eruption of the underlying contradictions out in time. Alternatively, the abrupt increase in the cost of financing after the outbreak of the crisis contributed as well to the large deterioration of $(r-i)$.

Nominal short term interest rates were $9.3 \%$ in 1995, falling thereafter to $2.1 \%$ in 2004-2005, while long term rates fell from $11.27 \%$ to less than $4 \%$ in $2005-2006$, which means a fall over $75 \%$ in the case of the former, and two thirds in the latter. After the crisis, while short term rates plummeted below $2 \%$, long rates remain at around $4-5 \%$. At the same time, the risk premium on the 10 -year German bond went from almost zero during the years of the economic boom to rise formidably. Since April 2010 it exceeded 100 basic points, amounting to 600 points at the end of July 2012, when it began to descend after the announcement of the possibility of intervention of the European Central Bank in support of the Euro (OECD, 2019).

The net profit rate of enterprise can be approximated by the index of the spread return on investment minus the cost of debt (Figure 5). As expected, this rate increases during the housing boom of the 2000s, mainly until 2004. It averaged 3.5 in the first six years, and the huge fall after 2006 lasted until 2012, amounting -95\%.

The best proof of the exogenous character of the fall of interest rates is the speculative dynamics that has contributed to feed around construction assets, mainly of residential type. This is clearly shown in the gap between long-term interest rates and the annual variation of the average housing price per 
square meter (Figure 6). From the third quarter of 1998 (1998Q3) it became positive, ranging from 1 to 4 points but since $2000 \mathrm{Q} 3$, the differential has been intensified both by the fall in nominal rates and by the increase in the rate of increase of housing prices, and between mid-2002 and 2005Q3 it turns out to be over 10 points. Therefore, the operation of borrowing at a cost that falls from $5.5 \%$ to $3.4 \%$ in order to acquire assets of which the average price increases by $7.7 \%$ in 2002 -but that between mid-2002 and early 2005 it does grow between 15 and 18\% annually- turned out to be a very easy, lucrative and absolutely logical activity from the business perspective. However, this differential started to fall since 2004Q1 -with a peak of 14.2 points- not because of interest rates, but when housing prices slowtheir rise, almost disappearing in the second half of 2007, and then turning negative in 2008.

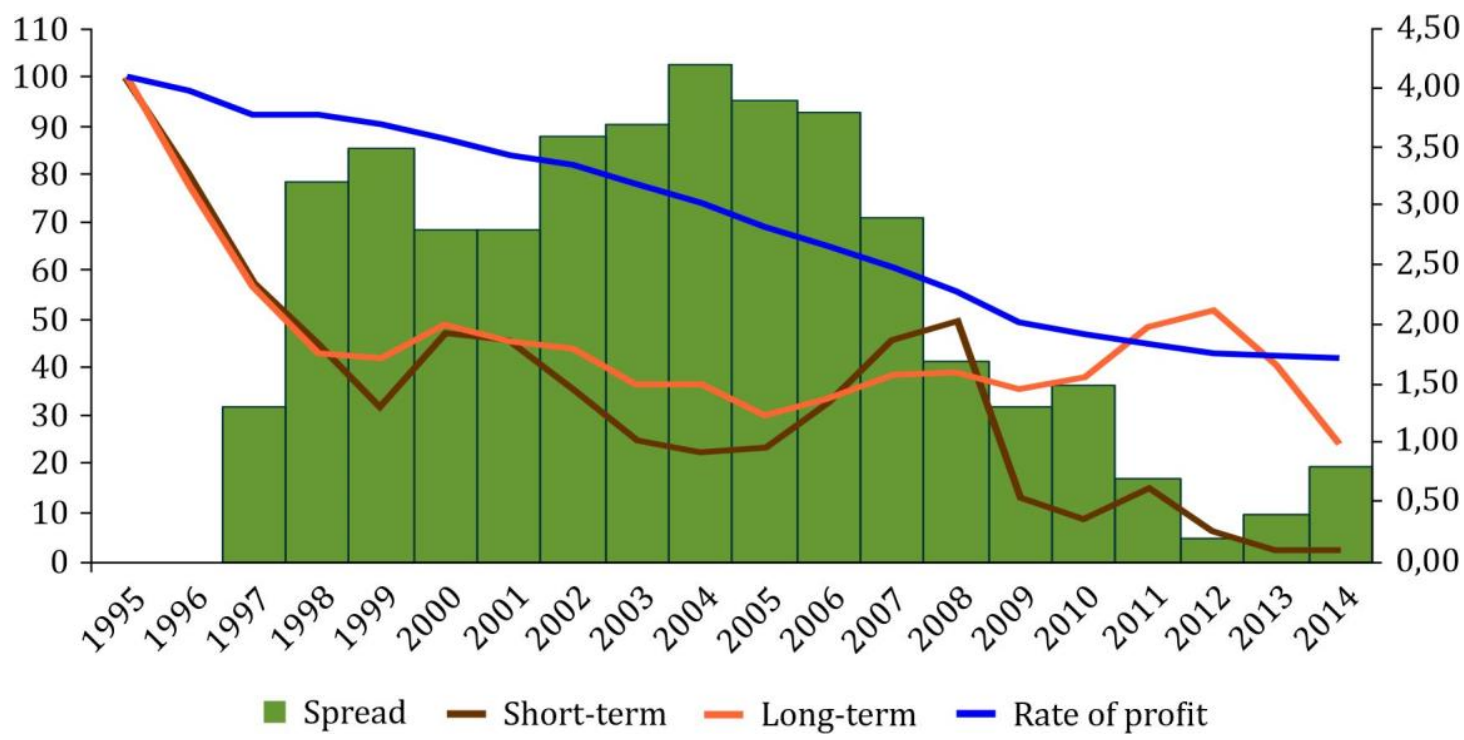

Figure 5. Comparative path of the profit rate, nominal interest rates and the spread return on investment over cost debt $(1995=100)$. Note: interest rates: short and long term. Sources: INE (2019a), Mas et al. (2011) and OECD (2019).

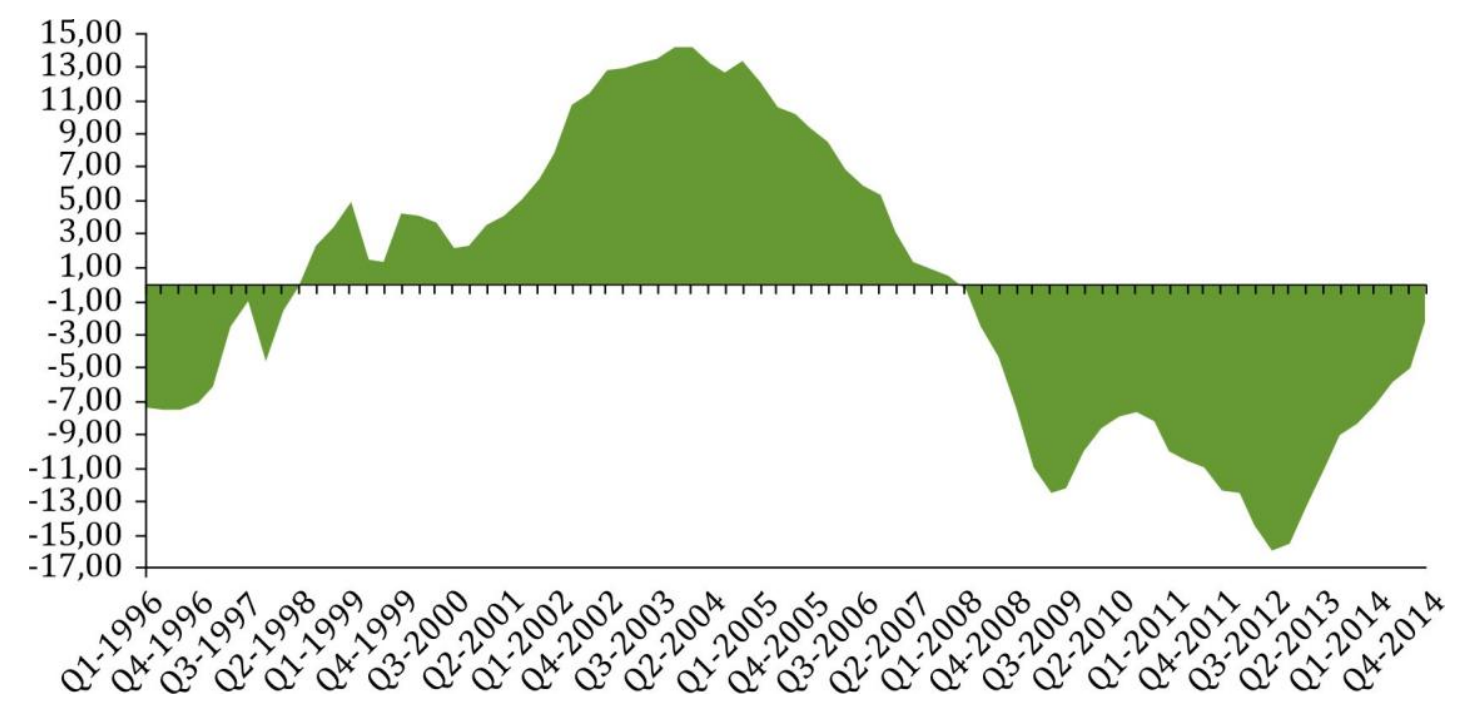

Figure 6. Gap between annual rates of change of housing prices and long term interest rates. Sources: Ministerio de Transportes, Movilidad y Agenda Urbana (2019) and OECD (2019). 
Under these circumstances, both households and NFC have increased their borrowing the most. NFC debt to GDP ratio increased from 44-45\% in the first three years of the period to exceed $120 \%$ in 2008 2011, while that of households surpassed $80 \%$ from 2008. By contrast, public debt went down from $63 \%$ to $36 \%$, but increased with the crisis, so that in 2012 it reached nearly $86 \%$. Globally, the growth period has been characterized by a high increase in the debt to GDP ratio, which doubled from 135 to more than 260\% in 2011-2014 (Banco de España 2019a).

This stock of debt represented a growing fraction of the corporate surplus until 2006. As shown in Figure 7, the ratio of the increase of the annual stock of debt (December to December) to total economic surplus went from less than $30 \%$ in the first two years of the series to a maximum of $82 \%$ in 2006 . If only the rise of NFC debt in relation to the surplus is considered, the evolution is relatively more intense although with a smaller percentage, from $4 \%$ to almost $70 \%$. Nevertheless, the same indebtedness in relation to just the NFC's GOS shows a still higher increase, from $8 \%$ to $121 \%$ in 2006 . As a result, NFC's net lending rose from $17 \%$ of gross fixed capital formation (GFCF) to over 40\% in 2006-2007 (OECD, 2019).

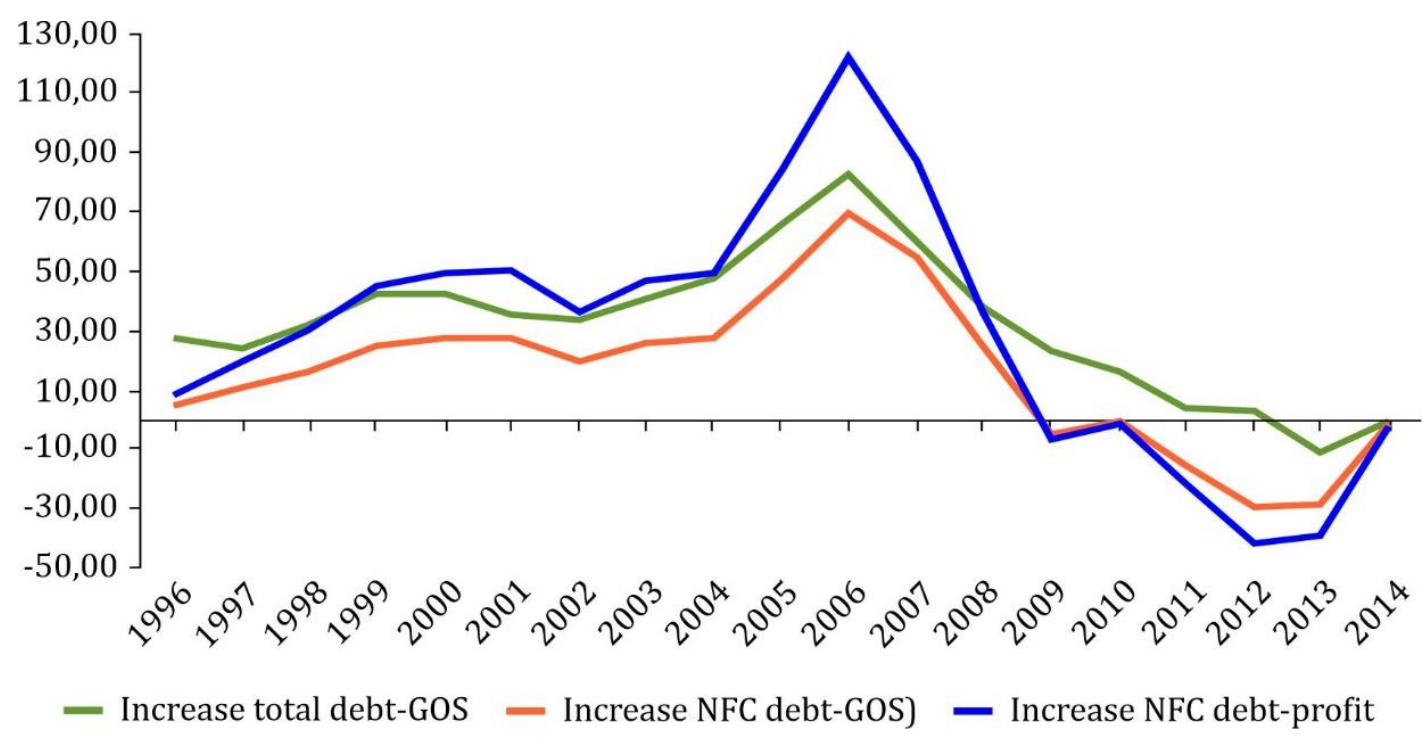

Figure 7. Increase in the stock of debt-surplus ratio. Notes: increase in: i) total stock of debt to total gross operation surplus (GOS); ii) non-financial corporations (NFC) stock of debt to GOS of productive activities; iii) NFC stock of debt to NFC gross prof it. Sources: Banco de España (2019a), INE (2019c) and OECD (2019).

The outstanding rise in these variation of debt-surplus ratios between 2004 and 2006 is the consequence of two interconnected and simultaneous processes, i) the above-mentioned slowdown in the still rising housing prices, as this process actually was the driving force of capital accumulation; and ii) the falling profit rate, in turn leading to an extraordinary increase in the stock of debt along those two years.

In other words, this rise of $(\Delta d e b t / P)$ means that the production of surplus has been even lower than what profit rate reveals, that is, with some kind fictitious character of the process of valorization. The consequence is shown after the outbreak of the crisis, when the flow of increased debt first slows down and since 2009 does fall in absolute terms for NFC, which is reflected in the negative sign of these series.

Correspondingly, the NFC's stock of debt to GOS and financial income (E2) (Banco de España, 2019a). has substantially increased in these years (Figure 8). In 1997, E2 was $237 \%$, with a further upturn only interrupted between 2002 and 2005, but then it reached a peak of $683 \%$ in 2012. This debt generated significant financial costs for NFC. Between 2004 and 2008, the interest burden doubled, from $12.9 \%$ to 
up to $25 \%$, exceeding $25 \%$ in 2011-2012. By company size, the interest burden was higher for small businesses, more than $30 \%$ of their profits in 2008-2012, and the gap with larger enterprises has been widening since 2008. In this sense, Maudos \& Fernández (2014, p. 42) conclude that "the problem of Spanish companies is not the average cost of the debt they support, but the burden that it represents and their reduced ability to give it back taking into account their low profitability".

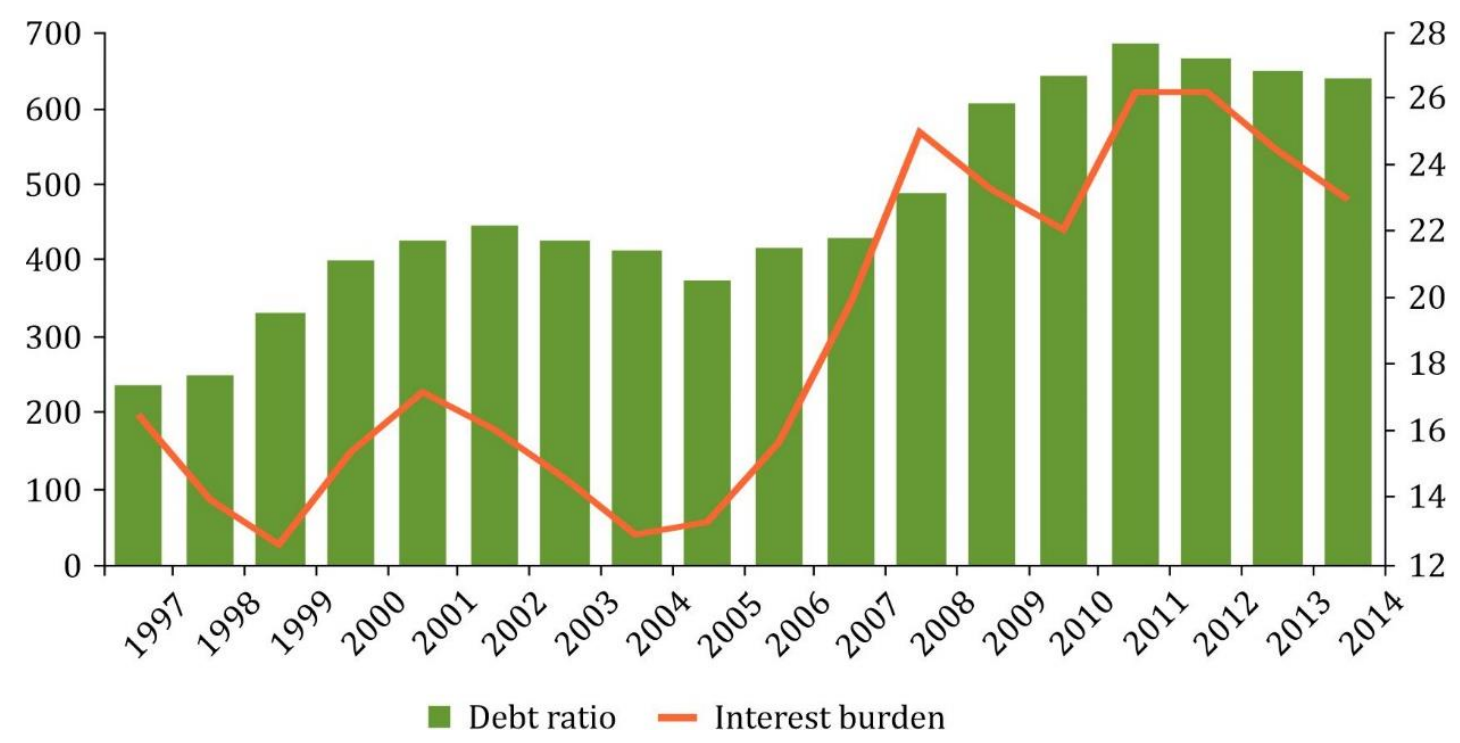

Figure 8. Debt ratio and interest burden of non-financial corporations. Debt ratio (E2, column left) and interest burden (\%, line right). Source. Banco de España (2019c).

However, what really happened is a transfer of income from both workers and the State towards private corporations, or a kind of financial expropriation, as claimed by Lapavitsas (2009). The counterpart then manifested itself as an increase in the indebtedness of the public sector and a restructuring of various dimensions of the wage relation. Although this issue goes beyond the purpose of this article, it is worth mentioning the reconfiguration not only of the real wage, but also of other dimensions such as indirect wages (regressivity of taxation and social expenditure) and deferred ones (stagnation of pensions and tightening the requirements to receive them). What is shown here is only an approximation to the true scope of the transfer of income from labor to capital. Given the sluggishness of investment, it probably infers the extraordinary extent of the crisis of valorization.

\subsection{Other measures of profitability}

Until 2006, three ratios show a cyclical pattern, ORNA, ORE and RE, with partial peaks in 1998 (ORNA), 2002 (ORNA and RE), 2004 (ORE), and finally in 2006-2007 for all of them (Figure 9). After this year, a general fall kicked off, and was intensified in 2008-2009 when the annual decline ranged from -10 to $-23 \%$. In the following years the slowdown continued at a slower, but significant pace. Between 2009 and 2012, RE fell at an average of $-4 \%$ per year, ORNA dropped by $-7.6 \%$, while the ORE reached an annual average of $-11.4 \%$, just to begin a slight recovery in the next two years.

While our rates of profitability $(P / K)$ showed the underlying problem, these conventional ratios have the advantage of showing a complementary perspective of a more concrete expression of profitability, which in relation to total assets and equity was not unfavorable in the years of the housing boom. The ORNA index does not fall between 2000 and 2006, despite the annual fluctuations, and profitability on equity, in turn, even increases between $3.7 \%$ and $10.4 \%$ in total (ORE and RE, respectively). On the other 
hand, the change of trend occurs in 2006-2007 in all cases, but is accentuated in 2008-2009, and the fall continues mainly until 2012.

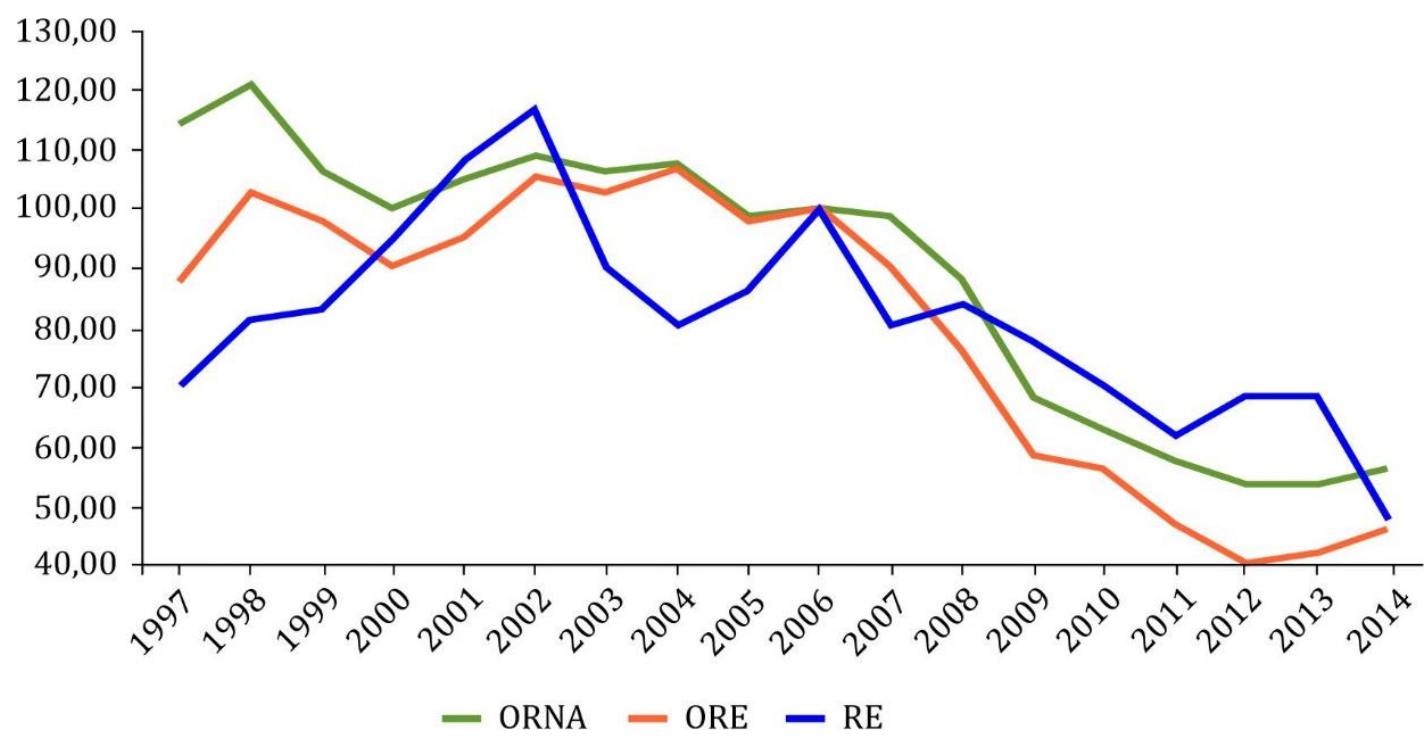

Figure 9. Conventional measures of profitability $(2006=100)$. Note: ordinary return of net assets (ORNA), ordinary return on equity (ORE), return on equity (RE). Source: Banco de España (2019c).

As these ratios incorporate both lower financial costs and higher opportunities due to the housing boom, they truly show the foundation of the investment boom. At the same time, the fall after 2006 was unsurprisingly higher, and so having a more pronounced volatility. Thus, between 2006 and 2014, the general profit rate drops by $-36 \%$, but these indices decline between by $-46 \%$ (ORNA) and almost $-60 \%$ (ORE), both in 2006-2012. This dichotomy reveals the form taken by the valorization process.

\subsection{International comparison: The profit rate in Spain and the Eurozone}

In this section a comparison is made of both the absolute level and the evolution of the general rate of profit of Spain in relation to a number of countries belonging to the center and periphery of the Eurozone: Austria (AUT), Belgium (BEL), Finland (FIN), Germany (GER) - the most advanced economies (center)-, France (FRA), Italy (ITA) -semi-central and semi-peripheral, respectively-, Greece (GRE), Ireland (IRE), Portugal (POR) and Spain (SPA) -Euro-periphery. As was expressed, this comparison is made with the OECD database (2019) except for Spain 8 .

The first issue to be highlighted is the center vs. periphery dichotomy, but with a tendency towards convergence after the economic crisis, or at least a reduction of their disparities -it should be clarified that there is no reason for the gross profit rate to converge. Regarding the level of profitability, the profit rate in Spain between 2000 and 2007 averages 20\%, below GRE and IRE -with averages of $42 \%$ and almost $41 \%$, respectively-, closer to ITA $(25 \%)$ and POR $(17.7 \%)$, and above the most advanced economies, which average $12 \%$ with the exception of FIN (17\%).

This hierarchy is maintained after the outbreak of the crisis but eased up. GRE and IRE had profit rates averaging 24\% and 28\% between 2008 and 2014, but the other peripheral economies, such as

${ }_{8}$ Capital stock data come from Fundación BBVA for Spain, as the OECD database (National Accounts/Detailed tables and simplified accounts/9A. Fixed assets by activity and by asset, ISIC rev4) does not provide series on the capital stock for Spain. Yet, only recently, the new 'STAN Industrial Analysis (2020 ed.) Database' (OECD, 2020) shows data, but only since 2001 $(t-1)$, so it is not useful for this research. The NOS is taken from OECD for all the countries, and excluding FIRE and GOV activities. 
POR, SPA and ITA, showed profitability levels ranging between $13 \%$ and $17 \%$, close to $12-13 \%$ of the more advanced economies -and FRA, 14.7\%. Therefore, the level of the profit rate reflects, to a large extent, the peripheral position of the Spanish economy in the Eurozone.

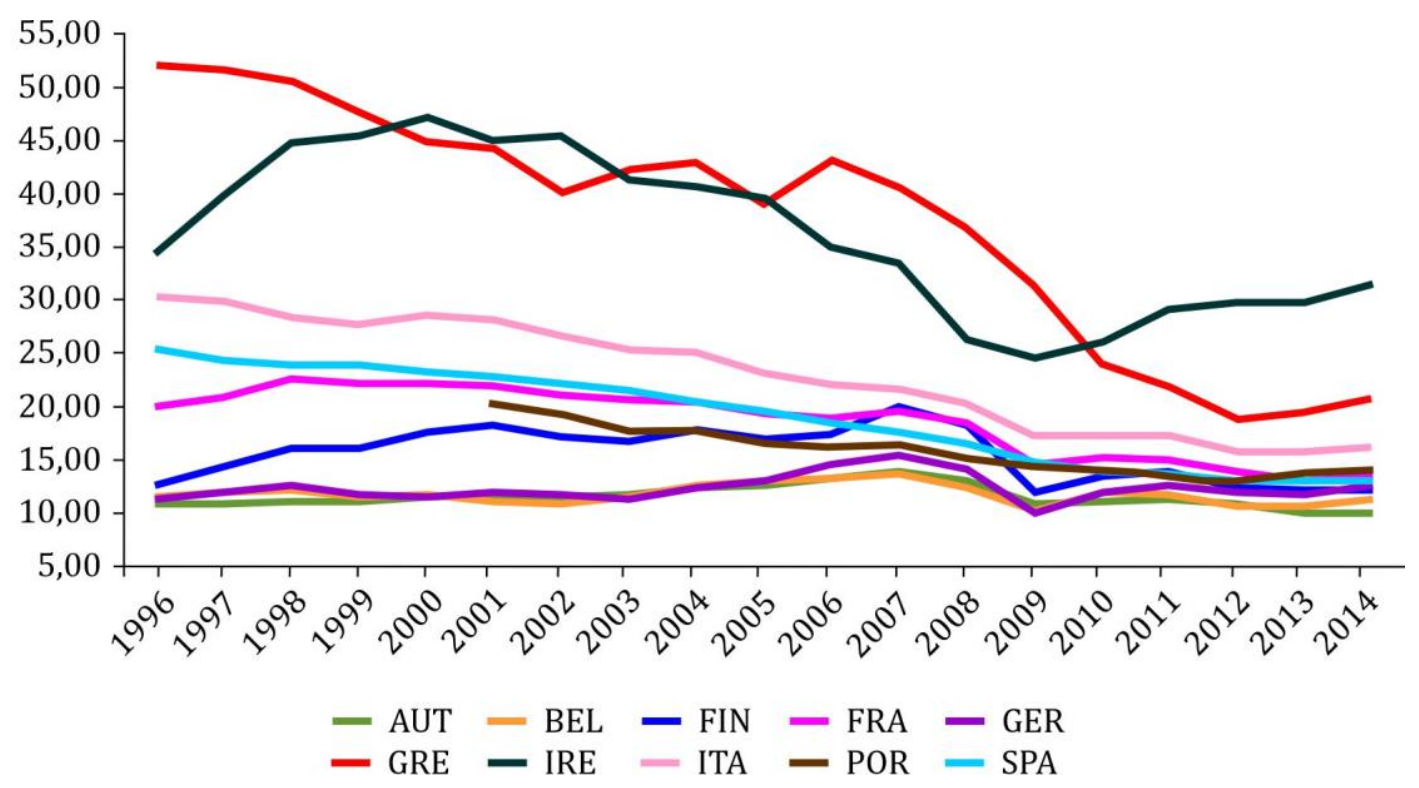

Figure 10. The profit rate: net surplus over net capital stock, productive activities (1996-2014) (\%). Note: the rate in POR excludes "agriculture, forestry and fishing", and data start only from 2001. Sources: Mas et al. (2011) and OECD (2019).

The second aspect is the evolution of this measure. Although the absolute levels were higher in the periphery, the decline in profitability has also been deeper in these economies, as can be seen in Table 1 . The center-periphery divide is clearly seen in the evolution of profitability prior to the outbreak of the crisis. Monetary integration has been accompanied by an increase of the profit rate in the most advanced economies (AUT, BEL, FIN and GER). From 1996, FIN has been an outstanding case, but since 2000, GER is the economy that better takes advantage of the EMU, raising its profit rate by a third in 7 years (2000-2007). The opposite evolution can be found in the group of peripheral economies, whose average profit rates falls until 2007, either taking the whole 1996-07 period, or just the 2000s. Even in FRA, profitability fell by $-11,7 \%$ in $2000-2007$.

Although the recession makes profit rates fall, the general evolution is still characterized by a centerperiphery asymmetry. Between 1996 and 2014, the decline amounts to 47-60\% in SPA, ITA and GRE, one third in POR since 2000, even another third in FRA, while IRE is an unusual case. Thus, it contrasts with the group of more advanced economies, in general with accumulated falls below 10\% (AUT, BEL, FIN). Again, GER appears as the "winner", as its profit rate shows an exceptional 12\% increase in 19962014.

In this framework, Spain stands out because of the deterioration of the profit rate as well as the incidence of indebtedness. First, the fall in profitability since 1996 (-49\%), is only exceeded by GRE $(60 \%)$, as also happens from 2000 . However, profitability in Spain declined more intensely before the crisis, $-31 \%$ since 1996, and especially during the height of the housing boom -since 2000 , the decline reaches $-24 \%$. In GRE, however, the fall in these subperiods is substantially lower, especially between 2000-2007 (-9.8\%), but it turns out to be higher after the Great Recession (-49\%).

Second, if debt is taken into account, this relative fall in profitability in Spain is even more pronounced. During the years leading up to the adoption of the Euro, the reduction in nominal interest rates in the short term (3-month interbank rate) and long term was relatively higher in the periphery, 
around 50\% in SPA, POR and ITA, but lower than GRE. It should be clarified that the average inflation in Spain between 2000 and 2007 surpassed that of these peripheral economies, including ITA (see European Commission, 2019). Consequently, the real fall in interest rates was higher in Spain. Although NFC consolidated debt to the GOS ratio in Spain was not exceptionally high in 1999 (OECD, 2019), the first year with data for this economy, it does rise relatively more than in the other economies (left side of Figure 11).

Table 1. Variation of profit rates (\%)

\begin{tabular}{lccccc}
\hline \multirow{2}{*}{ Countries } & \multirow{2}{*}{$1996-1997$} & $2000-2014$ & \multicolumn{2}{c}{$2000 \mathrm{~s}$} & \multirow{2}{*}{$1996-2014$} \\
\cline { 3 - 5 } & & & $2000-2007$ & $2007-2014$ & \\
\hline AUT & 27,18 & $-13,57$ & 20,99 & $-28,57$ & $-9,15$ \\
BEL & 18,88 & $-3,38$ & 17,07 & $-17,46$ & $-1,88$ \\
FIN & 59,34 & $-31,26$ & 13,02 & $-39,18$ & $-3,09$ \\
GER & 36,04 & 10,23 & 33,69 & $-17,55$ & 12,17 \\
FRA & $-2,32$ & $-39,65$ & $-11,77$ & $-31,60$ & $-33,18$ \\
ITA & $-28,58$ & $-43,86$ & $-24,32$ & $-25,81$ & $-47,02$ \\
SPA & $-31,12$ & $-44,15$ & $-24,24$ & $-26,28$ & $-49,22$ \\
POR & & $-33,27$ & $-19,88$ & $-16,71$ & \\
IRE & $-3,02$ & $-33,17$ & $-29,24$ & $-5,55$ & $-8,40$ \\
GRE & $-22,26$ & $-54,12$ & $-9,83$ & $-49,12$ & $-60,45$ \\
\hline
\end{tabular}

Note: the rate in POR excludes "agriculture, forestry and fishing", and data start only from 2001. Sources: Mas et al. (2011) and OECD (2019).

Between 1999 and 2007, when this ratio reaches the maximum of 6.30 (and only surpassed by POR, with 7.38, and a maximum in 2012 of 8.78), the total increase amounts to $68.1 \%$ in Spain. This path far outstrips all other economies, with ITA and GRE following, but at a certain distance, $45 \%$ and $36 \%$ respectively. Furthermore, the same happens with the increase in the stock of debt to GDP ratio, even with a larger gap in this case (Figure 11b).

a

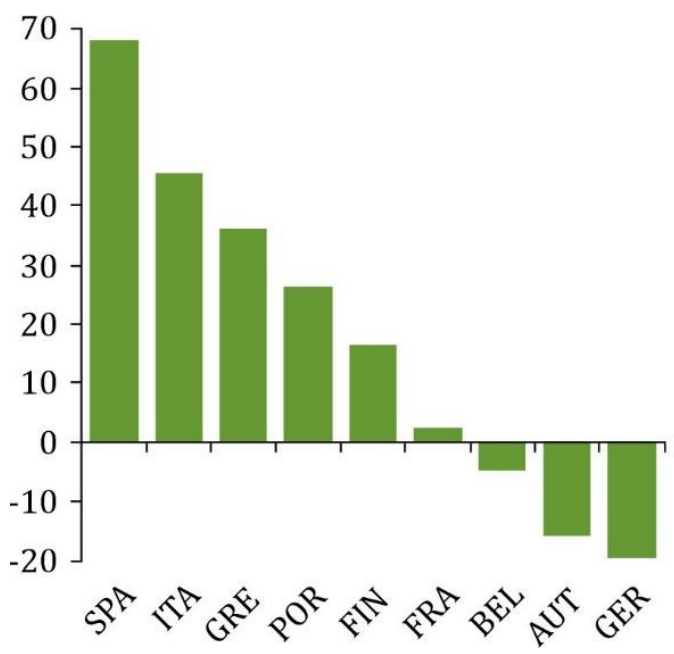

$\mathrm{b}$

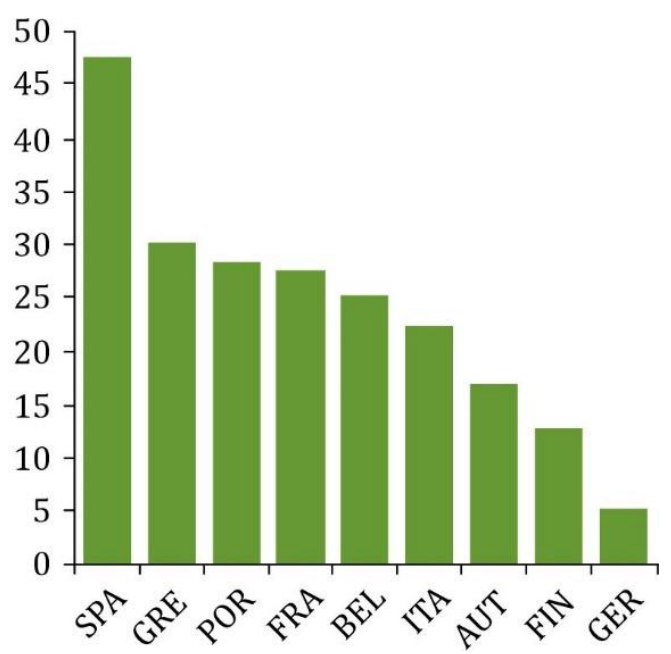

Figure 11. Rates of increase of debt ratios in 2000-2007. Note: accumulated variation (\%) in total debtGDP ratio (a) and NFC consolidated debt-GOS ratio (b). Source: OECD (2019). 
Therefore, it shows that the problem of profitability has even been more important in Spain in the post Euro stage when compared to other peripheral economies ${ }^{9}$. Yet, it took the form, or led to an increase of, indebtedness. Thus, this is why many accounts of the Spanish recession have focused in debt instead of the profit rate ${ }^{10}$.

\section{Conclusion}

This study has addressed the profitability of capital in the Spanish economy from 1995 to 2014 in order to show its central role in the long depression. The average gross profit rate of the total economy in 1995 was historically low, 30\% below the average for 1965-1974, and the subsequent expansion up to 2008 takes place while profitability declines. Besides, the exclusion of unproductive sectors is relevant because, aside from theoretical debates, the leading role of speculation (asset-inflation) around Real Estate activity together with the centrality of banking justify the disaggregated approach. Thus, the exclusion of both FIRE and GOV activities shows a deep fall in the profit rate, amounting to 58\%, almost 16 percentage points more than the measure for the whole economy.

Other adjustments confirm this assertion: i) the profit rate net of mixed income depends on the database, but even INE/OECD data reduces the fall by only 16 points, however consistent with the growing gap in profitability among large and SME; and ii) in relation to the capital stock, the GOS-inputs ratio falls by $-40 \%$ until 2007 , and despite the recovery afterwards, it nevertheless ends up with a drop of almost $30 \%$ until 2014, which would lead to an even higher fall in the profit rate if circulating capital was to be incorporated.

The comparison with conventional measures of profitability (ordinary return on net assets, ordinary return on equity and return on equity) has shown a steady or even upward evolution until 2006-2007, but with a subsequent extraordinary fall of $45-60 \%$ until 2012. This dynamic is explained by the housing boom and the proportionally higher decline in interest rates, between $60 \%$ and $70 \%$ for short and long term rates, respectively, which has compensated for the deterioration of the general profit rate through the impulse of the net profit rate of enterprise $(r-i)$.

As a result, a speculative process has been triggered, ultimately based on the reduced capacity to generate surplus, and the counterpart of which has been the formidable increase in indebtedness. Up to 2006, different measures of the increase of stock of debt to profit increase by 3 or even 13-14 times. Afterwards, the crisis raised the risk premium and the availability of credit plummeted, but the increase of the public debt and the wage regression become the counterparts through which the difficulties of valorization are manifested. Consequently, it is essential to integrate indebtedness in the analysis of the trends of the rate of profit, and mainly in the context of this so-called price effect.

Finally, the comparison with other EMU economies has shown, first, that the absolute level of the general profit rate in Spain corresponds to its peripheral insertion: lower than GRE and IRE, and close to that of ITA and POR. Also, the fall in Spanish profitability exceeds that of other economies during the period of economic growth (1996-2007), and for the whole period 1996-2014, it is only 10 points below Greece's outstanding drop, mainly because of the collapse of this economy after the outbreak of the crisis. However, the NFC's consolidated debt to GOS ratio experienced a more intense increase of $68 \%$ between 2000 and 2007, much higher than any other country. Ultimately, it can be stated that the problem in the capacity to generate surplus has been of the utmost relevance in Spain, as a historical, sectoral and regional analysis has clearly shown, which requires integrating indebtedness to a larger and complex issue of capital valorization.

This research makes it possible to highlight the relevance of profitability in the analysis of the imbalances of the upward phase of the cycle and the following recession. It constitutes a contribution

\footnotetext{
${ }^{9}$ For the IMF (2013), leverage ratios (debt to EBITDA) in Spain increased more than the other 4 economies of its study, even surpassing POR in 2008-2010.

10 See Mateo (2019) for an overview of these approaches and a critical analysis.
} 
regarding the basic lines of causality, thus i) it can be claimed that it would be low profitability that actually leads to high indebtedness, and not the other way around; then ii) both the stagnation of real wages, as well as the relative rise in wages at current prices, and by extension relative inflation and the consequent loss of profitability, could also be manifestations of underlying profitability problems; and iii) neither economic policy can be considered as the essential explanatory factor. These debates go far beyond the purpose of this article -I refer to Mateo (2019) for a deeper and systematic review of the literature-, but they reveal the importance of inquiring into the sphere of profitability as a possible foundation for macroeconomic dynamics.

\section{Acknowledgments}

This work was supported by the Ministerio de Economía, Industria y Competitividad of Spain, as part of the research project Modeling and simulation of energy transition scenarios towards a low carbon economy: The Spanish case (MODESLOW) (Ref: ECO2017-85110-R).

\section{References}

Albano de Freitas, A. (2017). Neoliberalism, profitability, and the crisis in the Eurozone. Review of Radical Political Economics, 49(3), 410-429. DOI: https://doi.org/10.1177/0486613417703955

Álvarez, N. (2012). La financiarización de la economía española. Endeudamiento, crisis y recortes sociales. Workshop on Debt. Berlín, 2-4 November 2012. Berlin, Germany: Rosa Luxemburg Stiftung. Retrieved from: https://colectivonovecento.wordpress.com/2012/11/08/la-financiarizacion-de-la-economia-espanolaendeudamiento-crisis-y-recortes-sociales/

Banco de España. (2019a). Boletín estadístico. Madrid: Banco de España. Retrieved from: https://www.bde.es/f/webbde/SES/Secciones/Publicaciones/InformesBoletinesRevistas/BoletinEstadistico /19/Fich/be noviembre2019 es.pdf

Banco de España. (2019b). Indicadores económicos. Madrid: Banco de España. Retrieved from: https://www.bde.es/webbde/es/estadis/infoest/indeco.html

Banco de España. (2019c). Central de balances. Sociedades no financieras. Madrid: Banco de España. Retrieved from: https://www.bde.es/bde/es/areas/cenbal/

Boundi, F. (2014). Tasa de beneficio y distribución del ingreso en la economía española (1964-2012). Ensayos de Economía, 44, 75-99. Retrieved from: https://revistas.unal.edu.co/index.php/ede/article/view/46421/47937

Brenner, R. (2006). The economics of global turbulence. London, UK: Verso.

Buendía, L., \& Molero-Simarro, R. (Coords.). (2018). The political economy of modern Spain. London, UK: Routledge.

Cámara, S. (2006). A value-oriented distinction between productive and unproductive labour. Capital \& Class, 30(4), 37-63. DOI: https://doi.org/10.1177/030981680609000104

Cámara, S. (2007). The dynamics of the profit rate in Spain (1954-2001). Review of Radical Political Economics, 39(4), 363-381. DOI: https://doi.org/10.1177/0486613407306822

Cámara, S. (2008). La dinámica global capitalista: un análisis de largo plazo en México, España y Estados Unidos. Trayectorias, 10(27), 47-64. Retrieved from: https://www.redalyc.org/articulo.oa?id=60712752006

Carballo-Cruz, F. (2011). Causes and consequences of the Spanish economic crisis: Why the recovery is taken so long? Panoeconomicus, 58(3), 309-328. DOI: https://doi.org/10.2298/PAN1103309C

del Río, A. (2015). La financiarización a debate: la desvinculación entre beneficios e inversión en el caso español. Investigación Económica, LXXIV(291), 53-77. DOI: https://doi.org/10.1016/j.inveco.2015.07.002

Estrada, A., Jimeno, J. F., \& Malo, J. L. (2009). La economía española en la UEM: los diez primeros años. Documentos Ocasionales №. 0901. Madrid: Banco de España. Retrieved from:

http://repositori.uji.es/xmlui/bitstream/handle/10234/113980/BancoEspana_Documentos\%20ocasionales 0901.pdf?sequence $=1$

European Commission. (2019). Macro-economic database AMECO. Brussels, Belgim: European Commission, Directorate General for Economic and Financial Affairs. Retrieved from: https://ec.europa.eu/info/businesseconomy-euro/indicators-statistics/economic-databases/macro-economic-database-ameco en 
Febrero, E., \& Bermejo, F. (2013). Spain during the Great Recession. Teetering on the brink of collapse. In O. Dejuán, E. Febrero \& J. Uxo (Eds.), Post-keynesian views of the crisis and its remedies (pp. 266-293). London, UK: Routledge.

Ferreiro, J., Gálvez, C., \& González, A. (2016). Financialisation and the economic crisis in Spain. In E. Hein, D. Detzer, \& N. Dodig (Eds.), Financialisation and the financial and economic crises. Country studies (pp. 89-113). Cheltenham, UK: Elgar.

Franconetti, F. J. (2015). Un ensayo comparativo sobre el ciclo económico a partir de un enfoque clásico basado en la evolución de la tasa de beneficio, la distribución de la renta y la desigualdad social: una panorámica internacional, de España y su desagregación por comunidades autónomas, a partir de la aplicación de filtros Hodrick-Prescott de series temporales. (PhD Thesis).

Retrieved from: http://e-spacio.uned.es/fez/view/tesisuned:CiencEcoEmp-Fjfranconetti

Guerrero, D. (2006). Explotación de los asalariados y ganancia capitalista en España (1954-2001). Razón y Revolución, 16, 13-56. Retrieved from: https://dialnet.unirioja.es/servlet/articulo?codigo=2170726

Guschanski, A., \& Stockhammer, E. (2020). Are current accounts driven by cost competitiveness or asset prices? A synthetic model and an empirical test. Cambridge Journal of Economics, 44(6), 1301-1327. DOI: https://doi.org/10.1093/cje/beaa013

Hossein-Zadeh, I. (2016). Marx on financial bubbles: Much keener insights than contemporary economists. Counterpunch (July 1). Pertrolia, CA: CounterPunch.

Retrieved from: https://www.counterpunch.org/2016/07/01/marx-on-financial-bubbles-much-keenerinsights-than-contemporary-economists/

INE. (2019a). Contabilidad nacional de España. Base 2010. Madrid: Instituto Nacional de Estadística. Retrieved from: https://www.ine.es

INE. (2019b). Directorio central de empresas. DIRCE. Madrid: Instituto Nacional de Estadística. Retrieved from: https://www.ine.es

INE.(2019c). Cuentas anuales no financieras de los sectores institucionales. Madrid: Instituto Nacional de Estadística. Retrieved from:

https://www.ine.es/dyngs/INEbase/es/operacion.htm?c=Estadistica C\&cid=1254736177054\&menu=result ados\&idp=1254735576581\#!tabs-1254736195672

INE. (2020). Contabilidad nacional anual de España: agregados por rama de actividad. Madrid: Instituto Nacional de Estadística. Retrieved from: https://www.ine.es/dyngs/INEbase/es/operacion.htm?c=Estadistica C\&cid=1254736177056\&menu=ultiDa tos\&idp=1254735576581

IMF. (2013). Global financial stability report. Washington, DC: International Monetary Fund. Retrieved from: https://www.imf.org/en/Publications/GFSR/Issues/2016/12/31/Old-Risks-New-Challenges

Jones, P. (2013). The falling rate of profit explains falling US growth. 12th Australian Society of Heterodox Economists Conference, 2-3 December 2013. Sydney, Australia. Sydney, Autralia: Australian Society of Heterodox Economists/University of New South Wales. Retrieved from: http://gesd.free.fr/jonesp13.pdf

Kliman, A. (2011). The failure of capitalist production. Underlying causes of the Great Recession. London, UK: Pluto Press.

Lapavitsas, C. (2009). Financialised capitalism: crisis and financial expropriation. Historical Materialism, 17(2), 114-148. DOI: https://doi.org/10.1163/156920609X436153

López, F., Dávila, L., \& López, J. (2013). Profits and extraordinary profits in the Spanish economy during the 2000 ’s. Aestimatio, 7, 28-47.

López, I., \& Rodríguez, E. (2011). The Spanish model. New Left Review, 69, 15-29. Retrieved from: https://newleftreview.org/issues/ii69/articles/isidro-lopez-emmanuel-rodriguez-the-spanish-model

López, J. (2015). The Levy-Kalecki profit equation in action: The Spanish case. Blog EOI. Retrieved from: https://www.eoi.es/blogs/the-spanish-paradox/2015/11/26/the-levy-kalecki-profit-equation-in-action-thespanish-case/

López, J., \& Palazuelos, E. (2016). Relación entre beneficios e inversión: crecimiento económico de España 19942007. Problemas del Desarrollo, 47(185), 109-134.

Retrieved from: http://www.scielo.org.mx/scielo.php?script=sci arttext\&pid=S0301-70362016000200109

Maito, E. E. (2018). The tendency of the rate of profit to fall since the nineteenth century and a world rate of profit. In G. Carchedi \& M. Roberts (Eds.), World in crisis (pp. 129-156). Chicago, IL: Haymarket.

Mas, M., Pérez, F. \& Uriel, E. (Dirs.). (2019). El stock y los servicios del capital en España y su distribución territorial y sectorial (1964-2016). Documentos de Trabajo 4-2011. Bilbao: Fundación BBVA.

Retrieved from: https://www.fbbva.es/wp-content/uploads/2017/05/dat/DT 042011 web.pdf 
Mas, M., Pérez, F., \& Uriel, E. (Dirs.). (2013). Inversión y stock de capital en España (1964-2011): evolución y perspectivas del patrón de acumulación. Informes 2013. Economía y Sociedad. Bilbao: Fundación BBVA. Retrieved from: https://www.fbbva.es/wp-content/uploads/2017/05/dat/DE_2013_Ivie_inversion_stock_capital_2011.pdf

Mateo, J. P. (2007). La tasa de ganancia en México, 1970-2003. Análisis de la crisis de rentabilidad a partir de la composición del capital y la distribución del ingreso. (PhD Thesis). Retrieved from: https://eprints.ucm.es/id/eprint/8126/

Mateo, J. P. (2011). The financialization as a theory of crisis in a historical perspective: Nothing new under the sun. PERI Working Paper Series 262. Amherst, MA: University of Massachusetts Amherst. Retrieved from: https://www.peri.umass.edu/publication/item/431-financialization-as-a-theory-of-crisis-in-a-historicalperspective-nothing-new-under-the-sun

Mateo, J. P. (2012). La actividad no capitalista y la composición del excedente en México. Análisis Económico, 27(64), 47-73. Retrieved from: http://www.analisiseconomico.azc.uam.mx/index.php/rae/article/view/206

Mateo, J. P. (2019). The theory of crisis and the Great Recession in Spain. London, UK: Palgrave.

Mateo, J. P. (2021). Theory and practice of crisis in political economy: The case of the Great Recession in Spain. Review of Radical Political Economics (forthcoming).

Mateo, J. P., \& Boundi, F. (2021). Rentabilidad del capital en el centro y la periferia de la Eurozona. Un análisis comparativo. Revista de Economía Mundial (forthcoming).

Maudos, J., \& Fernández, J. (2014). Endeudamiento de las empresas españolas en el contexto europeo. El impacto de la crisis. Bilbao: Fundación BBVA. Retrieved from: https://www.fbbva.es/wp-content/uploads/2017/05/dat/DE_2014 endeudamiento empresas.pdf

Mavroudeas, S., \& Papadatos, D. (2018). Is the financialization hypothesis a theoretical blind alley? World Review of Political Economy, 9(4), 451-476. DOI: https://doi.org/10.13169/worlrevipoliecon.9.4.0451

Milios, J., \& Sotiropoulos, D. (2009). Rethinking imperialism. A study of capitalist rule. Houndmills, Basingstoke: Palgrave Macmillan.

Ministerio de Transportes, Movilidad y Agenda Urbana. (2019). Información estadística. Madrid: Ministerio de Transportes, Movilidad y Agenda Urbana.

Retrieved from: https://apps.fomento.gob.es/BoletinOnline2/?nivel=2\&orden=35000000

Moseley, F. (2013). The U.S. economic crisis: From a profitability crisis to an overindebtedness crisis. Review of Radical Political Economics, 45(4), 472-477. DOI: https://doi.org/10.1177/0486613412475187

Muñoz de Bustillo, R. (2014). La crisis del nunca acabar. El comportamiento macroeconómico español 2008-2013. In N. García \& S. Ruesga (Coords.), ¿Qué ha pasado con la economía española? (pp. 55-82). Madrid: Pirámide.

Murillo, F. J. (2015). Análisis marxista del milagro económico español (1994-2007): dinámica salarial e impacto sobre la estructura de propiedad. (PhD Thesis).

Retrieved from: https://eprints.ucm.es/id/eprint/40722/1/T38204.pdf

Nieto, M. (2006). Tendencias de la rentabilidad y la distribución en el capitalismo español (1954-2003). Revista de Economía Institucional, 8(15), 185-206.

Retrieved from: https://dialnet.unirioja.es/servlet/articulo?codigo=5294618

OECD. (2019). OECD Database. Paris, France: Organization for Economic Co-operation and Development.

OECD. (2020). STAN industrial analysis (2020 ed.). Paris, France: Organization for Economic Co-operation and Development. Retrieved from: https://stats.oecd.org/Index.aspx?DataSetCode=STANI4_2020

Pérez, F. (Dir.). (2012). Crecimiento y competitividad. Motores y frenos de la economía española. Informe Fundación BBVA-Ivie 2012. Bilbao: Fundación BBVA. Retrieved from: https://www.fbbva.es/wpcontent/uploads/2017/05/dat/DE 2012 Ivie crecimiento competitivdad motores.pdf

Pérez Caldentey, E., \& Vernengo, M. (2018). Integration, spurious convergence, and financial fragility: A postKeynesian interpretation of the Spanish crisis. Brazilian Journal of Political Economy, 38(2), 304-323. DOI: http://dx.doi.org/10.1590/0101-31572018v38n02a05

Potts, N. (2010). Surplus capital: The ultimate cause of the crisis? Critique, 38(1), 35-49. DOI: https://doi.org/10.1080/03017600903454371

Prados de la Escosura, L. (2020). Capital in Spain, 1850-2019. Working Paper in Economic History 20-09. Madrid: Universidad Carlos III, Instituto Figuerola de Historia y Ciencias Sociales.

Roberts, M. (2016). The long depression. Chicago, IL: Haymarket.

Sanabria, A., \& Medialdea, B. (2016). Lending calling. recession by over-indebtedness: Description and specific features of the Spanish case. Panoeconomicus, 63(2), 195-210. DOI: https://doi.org/10.2298/PAN1602195M

Shaikh, A. (1999). Explaining the global economic crisis. Historical Materialism, 5(1), 103-144. DOI: https://doi.org/10.1163/156920699100414481 
Shaikh, A. (2016). Capitalism: competition, conflict, crises. New York, NY: Oxford University Press.

Shaikh, A., \& Tonak, A. (1994). Measuring the wealth of nations: the political economy of national accounts. Cambridge, UK: Cambridge University Press.

Trofimov, I. (2017). Profit rates in developed capitalist economies. A time series investigation. PSL Quarterly Review, 70(280), 85-128.

Retrieved from: https://ojs.uniroma1.it/index.php/PSLQuarterlyReview/article/view/13907

Vara, O. A. (2009). Causas de la crisis financiera en el caso español. Cuadernos de Economía, 32(88), $141-158$.

DOI: https://doi.org/10.1016/S0210-0266(09)70038-X

Wells, J. (2007). The rate of profit as a random variable. (PhD thesis).

Retrieved from: http://oro.open.ac.uk/22347/ 